\title{
Intervirology
}

Aherfi, S. 386, 424

Baud, D. 430

Bekliz, M. 354

Bertelli, C. 430

Boughalmi, M. 354, 386, 434

Colson, P. 354, 364, 376, 386, 413, 424

Desnues, C. 395

Diene, S.M. 364
Fournous, G. 364

Gaia, M. 354

Greub, G. 430

La Scola, B. $354,376,386,413,424,434$

Minodier, P. 424

Mueller, L. 430

Ngounga, T. 354,413
Pagnier, I. 354, 386, 413, 424, 434

Popgeorgiev, N. 395

Raoult, D. 347, 349, 354, 364, 376, 386, $395,413,424,434$

Reteno, D.-G.I. 354, 413, 424

Saadi, H. 354, 424

Slimani, M. 354, 434

Temmam, S. 395

\section{Subject Index Vol. 56, No. 6, 2013}

Acanthamoeba 354

- spp. 364

Amoeba 364, 376, 413

Archaea 349

Bacteria 349

Chlamydia 430

Codon bias 364

- usage 364

Cross-reactivity 430

Disease 376

Disinfection protocols 434

Eristalis tenax 386

Eukarya 349

Giant virus 386, 413

- viruses 434
Human stool 424

Humans 376, 395

Immunofluorescence 430

Lausannevirus 430

Marseilleviridae 364, 376, 386, 413, 430

Marseillevirus 354, 364, 376, 386, 413

Megavirales 349, 354, 364, 376, 413, 430

- detection 434

Megavirome 395

Megavirus 354

Mimiviridae 364, 376, 413

Mimivirus 349, 354, 364, 376, 413

Nucleocytoplasmic large DNA viruses 364

Papillomaviruses 395

Pathogenicity 376
Pneumonia 424

Prevalence 430

Real-time PCR 413

Serology 430

Shan virus 424

Sputnik 413

TRUC - Things Resisting Uncompleted Classifications 349

Viral flora 395

Virophage 354,413 